\title{
IODP Expeditions 304 \& 305 Characterize the Lithology, Structure, and Alteration of an Oceanic Core Complex
}

\author{
by Benoit lldefonse, Donna Blackman, Barbara E. John, Yasuhiko Ohara, D. Jay Miller, \\ Christopher J. MacLeod, and the IODP Expeditions 304-305 Scientists
}

\section{Introduction and Goals}

More than forty years after the Mohole Project (Bascom, 1961), the goal of drilling a complete section through in situ oceanic crust remains unachieved. Deep Sea Drilling Project - Ocean Drilling Program (DSDP-ODP) Hole 504B within the eastern Pacific (Alt et al., 1993) is the deepest hole ever drilled into ocean crust (2111 mbsf), but it failed to reach lower crustal plutonic rocks below the pillow basalts and sheeted dikes. IODP Expeditions 309 and 312 eventually recovered the long-sought transition from sheeted dikes into underlying gabbros by drilling into very fast-spreading Pacific crust (Wilson et al., 2006). The lithology and structure of oceanic crust produced at slow-spreading ridges are heterogeneous (e.g., Cannat et al., 1997) and offer unique drilling access to lower crust and upper mantle rocks. After
ODP Hole 735B penetrated $1500 \mathrm{~m}$ of gabbro at the Southwest Indian Ridge (Dick et al., 2000), IODP Expeditions 304 and 305 recently recovered just over $1400 \mathrm{~m}$ of little-deformed, gabbroic lower crust from a tectonic window along the slowspreading Mid-Atlantic Ridge.

IODP Expeditions 304 and 305 at the Atlantis Massif, Mid-Atlantic Ridge $30^{\circ} \mathrm{N}$, were designed to investigate the processes that control oceanic core complex (OCC) formation and exposure of lower crust and upper mantle rocks in young $(<2 \mathrm{Ma})$ oceanic lithosphere accreted at slow-spreading ridges. The corrugated, central portion of this domal massif (Fig. 1) displays morphologic and geophysical characteristics inferred to be representative of an OCC exposed via long-lived, low-angle, normal or detachment faulting (Cann et al., 1997; Blackman et al., 1998, 2004). Geophysical inter-

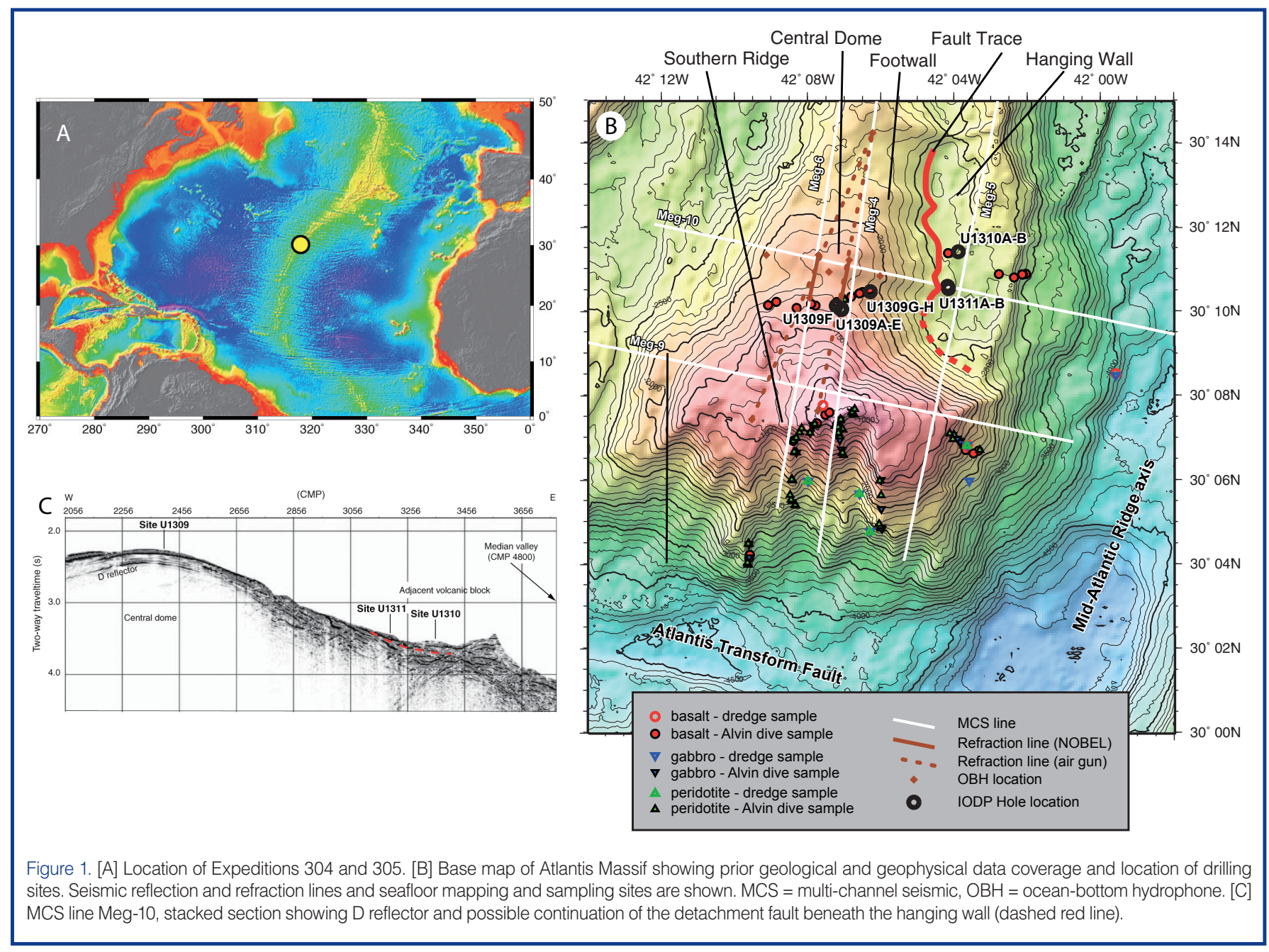


pretations suggested that unaltered mantle rock occurred $<1 \mathrm{~km}$ below the seafloor (Collins et al., 2003; Blackman et al., 2004; Canales et al., 2004), implying that drilling through an alteration front in ultramafic rocks could be achieved and that fresh mantle peridotite could be recovered at moderate depths. Additional objectives of drilling at the footwall concerned the dominant mechanism(s) of footwall uplift and the interactions between tectonics and magmatism in OCCs. Drilling within the hanging wall and through the detachment fault system was aimed at sampling and further constraining the latter and at assessing petrogenetic relationships between volcanic rocks in the hanging wall and potential source rocks recovered in the footwall.

We attempted drilling at three sites (Fig. $1[\mathrm{C}]$ ), one in the footwall through the inferred detachment fault and two in the hanging wall, but we did not succeed in drilling the fractured basalt in the hanging wall. In contrast, Hole U1309D, in the footwall of the detachment fault, penetrated $1415.5 \mathrm{~m}$ below the seafloor, and recovery averaged $75 \%$ (IODP Expeditions 304-305 Scientists, 2005). Shallow holes on the footwall provided limited samples whose composition and structure support the hypothesis that the corrugated dome coincides with an exposed detachment fault.

\section{Geological and Geophysical Background}

The Atlantis Massif formed within the past 1.5-2 My. and was exhumed along a detachment fault exposed over an 8-10-km-wide, $15-\mathrm{km}$-long area that forms the elongate, doubly plunging domal seafloor morphology (Fig. 1). Adjacent basaltic rocks to the east are interpreted as part of a hanging-wall block above the detachment fault. Multichannel seismic data (Canales et al., 2004) suggest that the fault system may dip gently under the seafloor at the base of the dome and continue at a shallow angle $\left(<15^{\circ}\right)$ beneath the eastern block toward the present-day ridge axis (Fig. 1C). The Southern Ridge is shallower than the central dome, shoaling to $700 \mathrm{~m}$ below sea level, and its corrugated surface extends eastward to the median valley wall.

Prior to IODP drilling, the core of the Atlantis Massif was inferred to comprise dominantly mantle peridotite. The peridotite-hosted, possibly serpentinization-driven Lost City hydrothermal vent field (Früh-Green et al., 2003; Kelley et al., 2005) is located just below the summit of the Southern Ridge, approximately $5 \mathrm{~km}$ south of Site U1309. Analysis of seismic refraction data across the central dome of the Atlantis Massif (Collins et al., 2003) indicated, at least locally, P-wave velocities of $\sim 8 \mathrm{~km} \cdot \mathrm{s}^{-1}$ within several hundred meters below the seafloor, possibly indicative of pristine mantle rocks. Interpretation of multi-channel seismic reflection data suggested a major difference in structure between the outside (conjugate) corner lithosphere versus that hosting the Atlantis Massif (Canales et al., 2004). A strong reflector is visible at $0.2-0.5 \mathrm{~s}$ below much of the domal surface and coincides roughly with the depth below which mantle velocities were inferred from the seismic refraction data. One interpretation of this "D reflector" suggested that it marks an alteration front within the peridotite-dominated massif. The multi-channel seismic (MCS) processing employed by Canales et al. (2004) resulted in the $\mathrm{D}$ reflector being quite continuous across the dome. A subsequent study by Singh et al. (2004) using different processing parameters to emphasize deep reflectivity produced a less continuous, but still pervasive interval of reflectivity whose top generally coincided with Canales' D reflector. Modeling of sea-surface gravity and sparse seafloor data (Blackman et al., 1998, 2004; Nooner et al., 2003) suggests that rocks beneath the central and southern dome have densities $200-400 \mathrm{~kg} \cdot \mathrm{m}^{-3}$ greater than rock to either side.

Rock samples collected from the central dome by the manned submersible Alvin are dominated by angular talus and rubble of serpentinized peridotite, metabasalt, and limestone (Blackman et al., 2004). A few samples from the central dome show cataclastic deformation or are highly serpentinized or metasomatically altered peridotite. The protolith of most of the serpentinite sampled on the south wall (Fig. 1) is inferred to be harzburgite. Talc-rich fault rocks preserve textural and geochemical characteristics of their ultramafic protoliths (Boschi et al., 2006). Microstructural analysis of samples from the south wall (Schroeder and John, 2004) indicates ductile deformation initially at granulite facies, overprinted by semi-brittle and brittle deformation down to subgreenschist facies. The observations and sample distribution suggest that strong semi-brittle and brittle deformation is concentrated at shallow structural levels ( $100 \mathrm{~m}$ beneath the domal surface) along the Southern Ridge (Schroeder and John, 2004; Karson et al., 2006). Rocks sampled from the hanging wall by manned submersible are wholly basalt (Blackman et al., 2004).

\section{Drilling at the Atlantis Massif Reveals Dominantly Gabbroic Core}

Igneous rocks recovered from Site U1309 span a broad range in composition, from the most primitive crustal rocks ever cored in slow-spreading oceanic lithosphere ( $\mathrm{Mg} \#$ up to 90) to highly evolved rock types (Fig. 2). To a first order, the gabbroic section can be divided into two major igneous units (Johnson et al., 2005). The upper unit extends to $\sim 600 \mathrm{mbsf}$ and broadly shows an increase downhole in olivine-rich rock types, although the detailed lithostratigraphy is more complicated. There is a sharp decrease in whole-rock $\mathrm{Mg \#}$ of the gabbros at $\sim 600$ mbsf (Fig. 2). Oxide-rich gabbros are concentrated in a zone between these upper and lower units. The lower unit also shows a general increase downhole in olivinerich rock types, with oxide-rich intervals near the base of the hole. At least two thin, mantle-peridotite intervals are recognized in the upper $180 \mathrm{~m}$ of the section, implying that the gabbroic section recovered in Hole U1309D was in part intruded into mantle peridotite. 


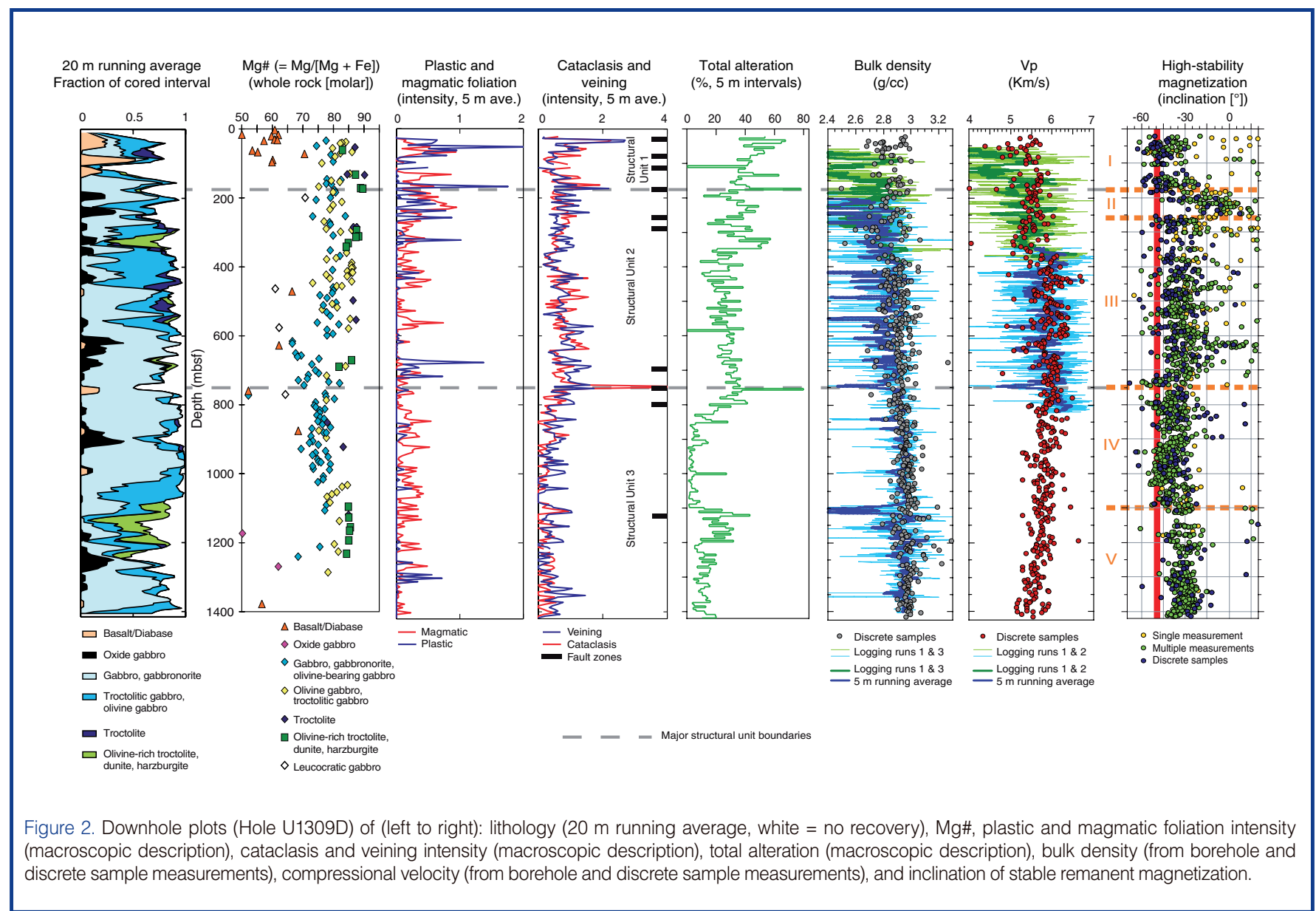

Holes U1309B and U1309D have interfingered lithologic units that vary in thickness from centimeters up to $100-200 \mathrm{~m}$ where intrusive contacts are preserved. Contact relations where visible between gabbro and other rock types, except diabase at Site U1309, suggest that gabbro is generally intrusive into more olivine-rich rock types, such as olivine gabbro and troctolite, and in turn intruded by felsic ("leucocratic") dikes and oxide gabbro. These relationships are more common between 400 and 650 mbsf than in the lower part of the hole, where gabbro contacts are commonly more diffuse. The 140 -m-thick interval of olivine-rich troctolite and minor associated lithologic units from 1094 to $1236 \mathrm{mbsf}$ in Hole U1309D forms an integral lithologic package that has been intruded by numerous crosscutting gabbroic dikes of variable thickness at temperatures below the troctolite solidus. Broader-scale contacts with adjacent olivine gabbro appear to be dominantly intrusive and formed under hypersolidus conditions. Late diabase intrusions are found in several places throughout Holes U1309B and U1309D.

The most abundant rock type recovered is gabbroic in composition and spans a wide range of modal composition, including minor (rarely exceeding a few percent) amounts of olivine, Fe-Ti oxides, and orthopyroxene. Gabbros and gabbronorites exhibit significant variation in grain size $(<1 \mathrm{~mm}$ to $>10 \mathrm{~cm}$ ), occasionally within a single section of core. Olivine gabbro, the second-most abundant rock type, has highly variable modal compositions on a submeter scale and grades locally into troctolitic gabbro; it is commonly spatially associated with troctolites. A series of olivine-rich rocks ( $\sim 5 \%$ in hole U1309D; dunites, wehrlites, troctolites), grouped as olivine-rich troctolites, are interlayered with gabbroic rocks. In contrast to troctolite, olivine-rich troctolite displays subhedral to rounded medium-grained olivine and interstitial to poikilitic plagioclase and clinopyroxene in variable proportions. These rocks may represent primitive cumulates.

Fe-Ti oxide gabbro, resulting from pervasive, latemagmatic-stage infiltration of evolved melt, composes $7 \%$ of the rocks recovered from Hole U1309D. The most common occurrence of oxide concentrations $(\sim 80 \%$ of the oxide gabbros) is seen as randomly dispersed patches in undeformed, generally coarse-grained gabbro. They are also found as discrete dikelets or layers cutting other rock types with either sharp or diffuse boundaries, and associated with intervals of ductile deformation.

\section{Structure and Alteration}

The core from Hole U1309D can be divided structurally into three major units (Fig. 2):

- Structural Unit 1 (0-170 mbsf) is marked by a high but decreasing degree of cataclasis downhole; abundant, late, relatively undeformed diabase; a high degree of green- 
schist-grade alteration; and a near-present-day orientation of the paleomagnetic inclination. The boundary to structural Unit 2 at $\sim 170$ mbsf is marked by a subhorizontal to moderately dipping crystal-plastic shear zone within gabbroic rocks, a high intensity of veining, strong cataclasis, and a $\sim 2$-m-thick interval of altered ultramafic rocks.

- Structural Unit 2 ( 170 to $\sim 785 \mathrm{mbsf})$ is marked by a relatively high intensity of veining, including the presence of sulfide minerals. Paleomagnetic inclinations are $\sim 10^{\circ}-30^{\circ}$ shallower than present-day values. The base of structural Unit 2 is defined by a series of greenschistgrade cataclastic fault zones between 695 and 785 mbsf.

- Structural Unit 3 extends beyond 785 mbsf and is characterized by an overall low intensity of cataclastic deformation, veining, and plastic deformation.

Overall, the section is moderately altered at conditions ranging from granulite to zeolite facies and dominated by static, greenschist facies assemblages. Pseudomorphs of igneous textures remain largely unmodified. Magmatic deformation fabrics, as defined by the preferred orientation of plagioclase, were recorded in $22 \%$ of the recovered rocks. These fabrics are weak to very weak, except in local intervals, and tend to be developed more clearly in gabbroic rocks with finer initial grain size; foliation is also well developed in the rare layered intervals. In many places, weak crystal-plastic deformation seems to overprint magmatic foliations (Fig. 3). High-strain, crystal-plastic shear zones are rare (Figs. 2 and 3) and are typically restricted to clearly defined, mostly granulite-grade shear zones ranging in width from millimeters to a few meters. This contrasts markedly with the much larger number of high-strain shear zones recorded in the gabbroic complex at ODP Site 735B (Fig. 3A) on the Southwest Indian Ridge (Dick et al., 1999, 2000). Vein intensity in Hole 1309D decreases significantly below 785 mbsf (Fig. 2) and tends to correlate with cataclastic deformation in general and with fault zones on a local scale. On the scale of the entire core, there is no systematic, lithologydependent distribution of vein type downhole. The amount of strain recorded by brittle fracture and cataclasis is limited overall, except for a few fault zones concentrated in the upper $50 \mathrm{~m}$ of Hole U1309D and in discrete intervals downhole, some of which correspond to the boundaries of the defined major structural units, in particular at $~ 750$ mbsf (Fig. 2). Cataclasis is associated locally with oxide gabbro intervals and dikelets, leucocratic veins, and contact zones between diabase intrusions and their gabbroic host rocks.

The lack of significant structures indicative of high displacement by either ductile or brittle processes severely limits the possible thickness of fault zones that could compose a detachment system over the central dome. Poor recovery of the upper $20 \mathrm{~m}$ of the footwall allows the possibility that this narrow zone accommodated very high strain along a dominantly brittle fault, as documented at the $15^{\circ} 45^{\prime} \mathrm{N}$ OCC (MacLeod et al., 2002; Escartín et al., 2003). If so, the fault zone thickness differs from the 50-100 m estimates at the Southern Ridge (Williams et al., 2003; Schroeder and John, 2004; Karson et al., 2006). This difference results either from a decreasing thickness of the fault from the south to the center of the dome or from an overestimated thickness at the Southern Ridge because of limitations in accurately determining the structural depth of submersible samples. Extensive amphibolite facies deformation is lacking, and high-strain ductile shear zones are rare. The absence of a thick zone of high-temperature ductile deformation in the footwall and the apparent tectonic history (less rotation in the upper $180 \mathrm{~m}$ and variable rotations between several distinct, few-hundred-meter sections downhole, Fig. 2) suggested by paleomagnetic inclination measurements indicate complexity in structural evolution that differs from a simple model of a deep-rooted detachment fault, predicted to be associated with high-temperature deformation, and with constant or monotonically varying footwall rotation with depth.

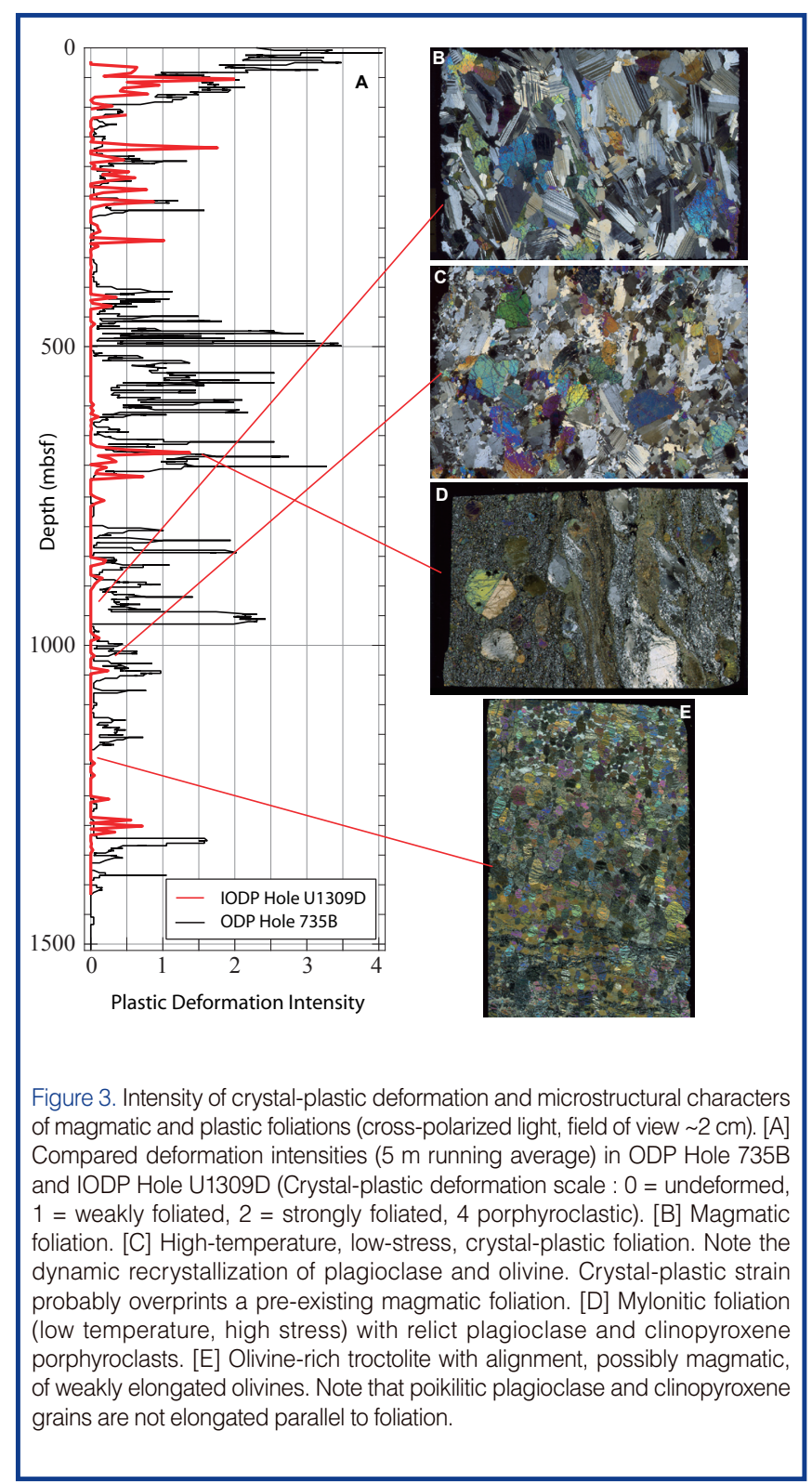


Altered mineral assemblages in rocks from Site U1309 record cooling of mafic plutonic rocks from submagmatic conditions $\left(>1000^{\circ} \mathrm{C}\right)$ to zeolite facies temperatures $\left(<200^{\circ} \mathrm{C}\right)$ during the unroofing and uplift of the Atlantis Massif. Individual samples generally display a range of superimposed metamorphic conditions, but no single sample records the entire cooling history of the site. Overall, alteration intensity is moderate, tends to decrease downhole, and is commonly related to vein intensity (Fig. 2). Local exceptions to this general downhole decrease in alteration intensity often correlate with an increase in modal abundance of olivine. Coarser-grained gabbro intervals are generally more altered than medium- to coarse-grained units. Intervals of olivine-rich troctolite show alteration restricted to heterogeneous serpentine networks, with strong alteration gradients from the contact with intensely veined intercalated gabbros to fresher cores. The latter contain local intervals of very fresh (as low as $1 \%$ serpentinization) olivine-rich (as much as $>90 \%)$ rocks.

The metamorphic and alteration history recorded at Site U1309 is summarized as follows:

1. High-temperature, near-solidus, mylonitic deformation and recrystallization at granulite- to upper-amphibolitefacies conditions.

2. A widespread, largely static upper-greenschist-facies to lower-amphibolite-facies event (Figs. 2 and 4). The upper $\sim 380$ m of the core shows a beautiful alteration profile with evidence for pervasive static infiltration of seawater with decreasing temperature. In addition, these same rocks show localized alteration superimposed in some cases on pervasive alteration, presumably reflecting localized fluid flow and metasomatism. Below this depth, alteration is generally restricted to halos around veins, fractures, and igneous contacts.

3. Static, lower greenschist to subgreenschist metamorphism. Serpentinization above $\sim 300 \mathrm{mbsf}$ is restricted to rocks where olivine was in excess over plagioclase and was therefore still present after the corona-forming reaction between olivine and plagioclase (stage 2) went to completion. At deeper levels, serpentine, prehnite, and hydrogrossular are often localized on closely spaced, variably oriented fractures.

\section{Correlations Between Alteration and Geophysical Signature}

Downhole logging and physical property measurements on core samples do not correlate strongly with rock type (Fig. 2). Instead, alteration may play a stronger role in determining the geophysical signature of the upper $1.5 \mathrm{~km}$ of the central dome. Average sample density varies only slightly, from $2.800 \mathrm{~g} \cdot \mathrm{cm}^{-3}$ in the upper $380 \mathrm{mbsf}$ to $2.900 \mathrm{~g} \cdot \mathrm{cm}^{-3}$ in the lower $\sim 1 \mathrm{~km}$ (Fig. 2). Meter-scale intervals show more variability in both sample and logging measurements, with oxide gabbro sometimes reaching $>3.200 \mathrm{~g} \cdot \mathrm{cm}^{-3}$ and highly altered olivine-rich zones dropping to $<2.700 \mathrm{~g} \cdot \mathrm{cm}^{-3}$. Average compressional velocity is $5.6 \mathrm{~km} \cdot \mathrm{s}^{-1}$ in the upper $\sim 400 \mathrm{~m}$ and $5.8 \mathrm{~km} \cdot \mathrm{s}^{-1}$ for the interval $\sim 00-800 \mathrm{mbsf}$. The mid-expedition checkshot experiment extended to $840 \mathrm{mbsf}$, the base of the hole at that stage. Instrument failure and poor weather

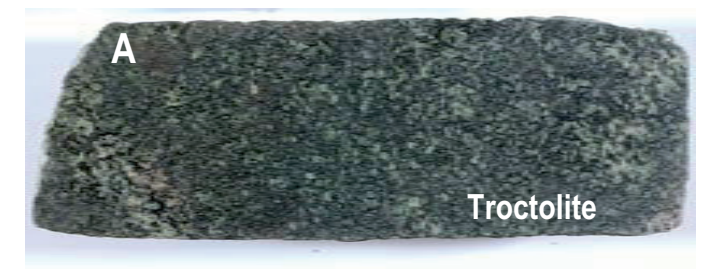

$\begin{array}{llllllllllllllll}50 & 59 & 52 & 53 & 54 & 55 & 55 & 57 & 58 & 59 & 60 & \text { at } & 50 & \text { b3 } & \text { b4 } & 65\end{array}$

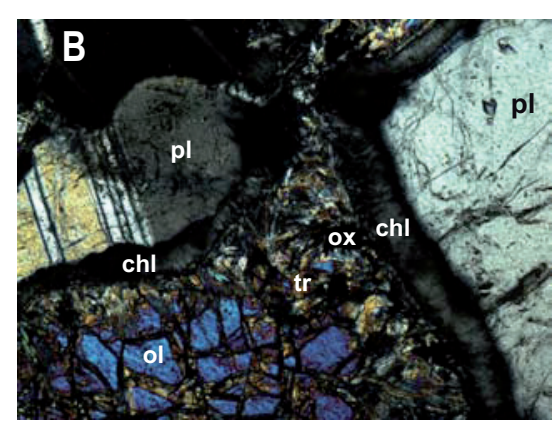

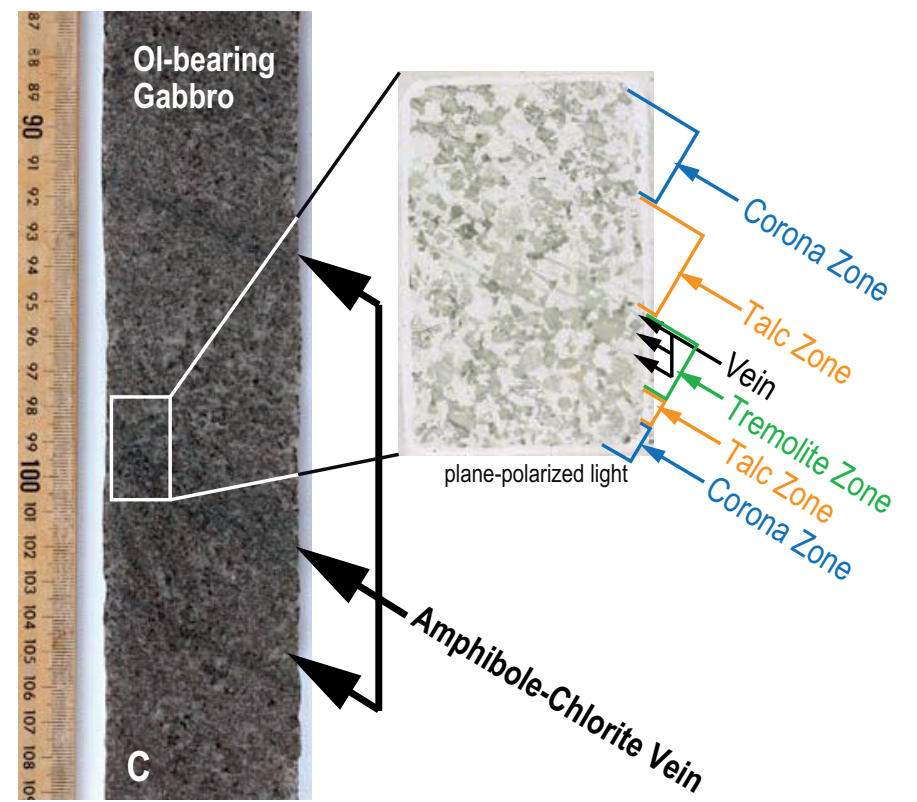

Figure 4. Most common alteration patterns. [A] Corona mesh texture in troctolite layer (Hole U1309B, 77 mbsf). [B] Thin-section photomicrograph of a corona texture in olivine gabbro consisting of talc, tremolite, oxides after olivine, and chlorite after plagioclase where the two original minerals were in contact (Hole U1309D, 403 mbsf, cross-polarized light, field of view 1.4 mm). [C] Example of alteration halo around chlorite-amphibole-rich veins (Hole U1309D, 941 mbsf). 
precluded acquisition of seismic data in the final logging run. Seismic velocity values obtained by sample and sonic log measurements range from $\sim 5.1$ to $6.8 \mathrm{~km} \cdot \mathrm{s}^{-1}$. Values less than $5.5 \mathrm{~km} \cdot \mathrm{s}^{-1}$ are common in the upper $180 \mathrm{mbsf}$ and in the olivinerich interval $\sim 280-380$ mbsf, below which values near $6 \mathrm{~km} \cdot \mathrm{s}^{-1}$ are most common. Only thin intervals have a velocity greater than $6.5 \mathrm{~km} \cdot \mathrm{s}^{-1}$ corresponding to olivine gabbro or olivine-rich troctolite units with little alteration.

Shipboard processing of the checkshot data revealed only first-arrival information. Although the signal-to-noise ratio was generally good for the stacked data, considerable noise was present due to impacts of the pipe in the upper part of the hole. After the expedition, individual traces were analyzed, and particularly noisy records were removed prior to re-stacking and bandpass filtering (5-120 Hz). The processed data (Fig. 5) show a secondary arrival that trails the first peak by a time that decreases from $41 \mathrm{~ms}$ to essentially zero between stations at 275 and 435 mbsf. Using the delays at the 275 and $345 \mathrm{mbsf}$ stations and a velocity of $5.5 \mathrm{~km} \cdot \mathrm{s}^{-1}$, a reflector at $\sim 390 \mathrm{mbsf}$ could produce the secondary arrival that also corresponds to a strong reflector on the MCS line closest to Hole U1309D. It is likely that this represents the D reflector in this part of the dome.

The temperature-acceleration-pressure (TAP) tool recorded a temperature of $120^{\circ} \mathrm{C}$ at the bottom of the hole (Fig. 6). Temperature increased with depth as expected but was somewhat lower than predicted from a simple cooling-

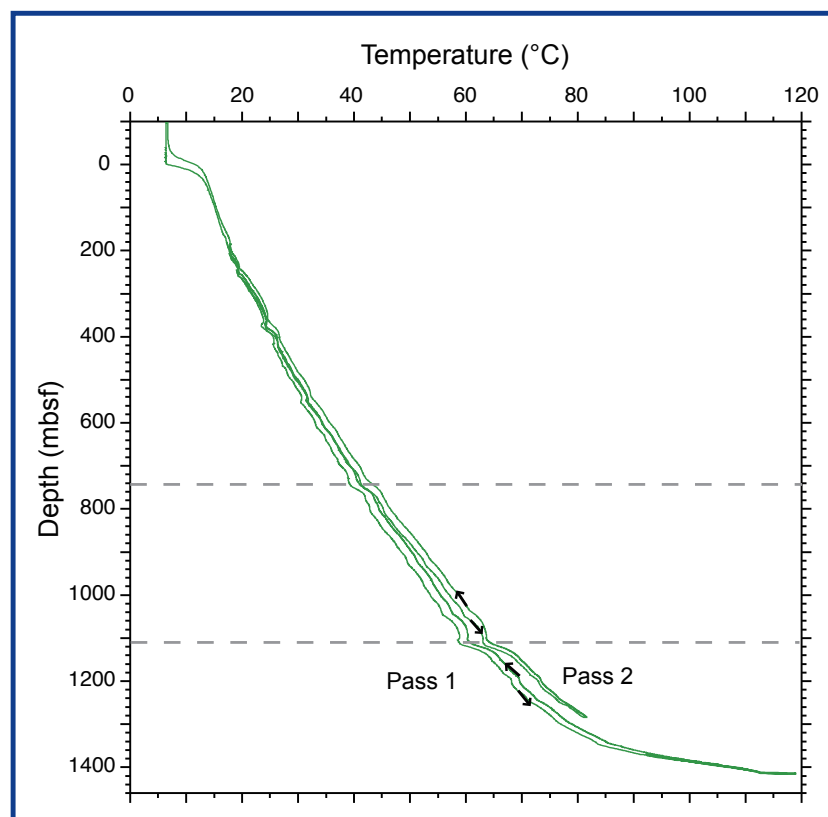

Figure 6. Temperature recorded by TAP tool. Increase in borehole temperature with time is recorded during downhole and uphole logging runs and during repeated logging passes. Dashed lines indicate recognized fault zones (see Fig. 2) which coincide with local dips in temperature.

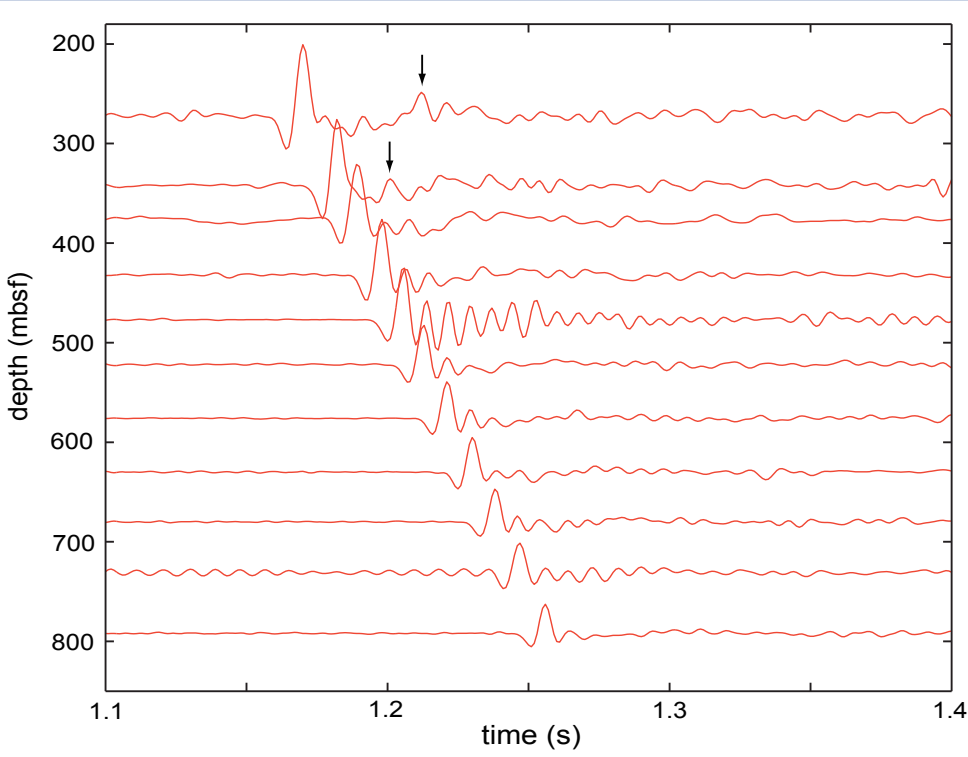

Figure 5. Filtered waveforms for checkshot experiment in upper part of Hole U1309D. Main arrival has strong signal-to-noise ratio. Removal of especially noisy traces brings out character of later arrivals. At upper stations, a secondary arrival (arrows) probably corresponds to D reflector of Canales et al., (2004).

plate model of a spreading ridge flank with an age of $\sim 2 \mathrm{Ma}$. The measured temperatures are a minimum estimate, however, because of hole cooling during coring. These initial results suggest that thermally driven flow is likely to occur in the hole. Several drops of a few degrees were recorded in narrow intervals (two of which coincide with documented fault zones at $\sim 750$ and $1110 \mathrm{mbsf}$ ) on repeated TAP runs (Fig. 6), perhaps indicating localized fluid flow.

\section{Concluding Remarks}

Igneous rocks recovered at Site U1309 provide an exceptional record of magmatic accretion, tectonic exposure, and hydrothermal alteration in a slow-spreading ridge environment. The exposures of peridotite along the southern wall of the Atlantis Massif, the geophysical results suggesting that at least portions of the dome contain fresh olivinerich rock (possibly olivine-rich troctolites), and the downhole variability at Site U1309 all likely indicate significant lateral lithological heterogeneity over distances as short as hundreds of meters across the footwall.

The Atlantis Massif is the fourth location where drilling an OCC (i.e., a corrugated massif, or an inside corner high capped by fault rocks) at a slow-spreading ridge has been attempted by ODP or IODP. A total of fourteen holes ( $>10 \mathrm{~m}$ deep) were cored at seven different sites in three different OCCs during ODP Legs 118, 153, 176, 179, and 209 (Robinson, et al., 1989; Cannat, et al., 1995; Dick, et al., 1999; Pettigrew et al., 1999; Kelemen, et al., 2004). Those efforts recovered only gabbroic sections, ranging from Fe-Ti oxide gabbros to troctolites, locally intruded by diabase. The latest result $\mathrm{s}$ of IODP Expeditions 304 and 305 point to the need for a new paradigm of crustal accretion in regions that are classically inferred to be representative of magma-starved portions of 
the ridge. One possible working model relates the development of OCCs to the occurrence of periodically larger gabbroic bodies beneath slow-spreading ridge segment ends (Ildefonse et al., 2006). Uplift and exhumation of these gabbroic bodies would be enabled by deformation that localized predominantly within the serpentinized peridotite that initially surrounded them. The northward extension, inside the core of the Atlantis Massif, of the serpentinites outcropping at the southern wall is presently unknown. These serpentinites could represent a relatively thin sheet of mantle rocks surrounding a dominantly gabbroic core. Alternatively, a significant, but unknown part of the Atlantis Massif footwall may be composed primarily of serpentinite and peridotite. Further IODP operations in this region should combine deeper drilling in Hole U1309D and drilling the southeast shoulder of the Atlantis Massif.

\section{Acknowledgements}

We thank Captains Pete Mowat and Alex Simpson, the operation superintendents Mike Storms, Stephen Midgley, and Ron Grout, the crew of the JOIDES Resolution, and the IODP United States Implementing Organization's technical staff for their commitment and hard work during Expeditions 304 and 305.

\section{IODP Expeditions 304 and 305 Scientists}

D. Blackman (Co-Chief Scientist), B. Ildefonse (Co-Chief Scientist), B.E. John (Co-Chief Scientist), Y. Ohara (Co-Chief Scientist), D.J. Miller (Expedition Project Manager/Staff Scientist), C.J. MacLeod (Shore-based Contributor), N. Abe, M. Abratis, E.S. Andal, M. Andréani, S. Awaji, J.S. Beard, D. Brunelli, A.B. Charney, D.M. Christie, A.G. Delacour, H. Delius, M. Drouin, F. Einaudi, J. Escartin, B.R. Frost, P.B. Fryer, J.S. Gee, M. Godard, C.B. Grimes, A. Halfpenny, H-E. Hansen, A.C. Harris, A.T. Hasebe, N.W. Hayman, E. Hellebrand, T. Hirose, J.G. Hirth, S. Ishimaru, K.T.M. Johnson, G.D. Karner, M. Linek, J. Maeda, O.U. Mason, A.M. McCaig, K. Michibayashi, A. Morris, T. Nakagawa, T. Nozaka, M. Rosner, R.C. Searle, G. Suhr, M. Tominaga, A. von der Handt, T. Yamasaki, and X. Zhao.

\section{References}

Alt, J.C., Kinoshita, H., Stokking, L.B., et al., 1993. Proc. ODP, Init. Repts., 148: College Station, Texas, U.S.A. (Ocean Drilling Program).

Bascom, W.N., 1961. A Hole in the Bottom of the Sea: The Story of the Mohole Project. Garden City, New York (Doubleday and Company, Inc.).

Blackman, D.K., Cann, J.R., Janssen, B., and Smith, D.K., 1998. Origin of extensional core complexes: evidence from the MAR at Atlantis fracture zone. J. Geophys. Res., 103:21315-21334. doi:10.1029/98JB01756

Blackman, D.K., Karson, J.A., Kelley, D.S., Cann, J.R., Früh-Green, G.L., Gee, J.S., Hurst, S.D., John, B.E. Morgan, J., Nooner, S.L., Ross, D.K., Schroeder, T.J., and Williams, E.A., 2004.
Geology of the Atlantis Massif (MAR $30^{\circ} \mathrm{N}$ ): implica tions for the evolution of an ultramafic oceanic core com plex. Mar. Geophys. Res., 23:443-469. doi:10.1023/B: MARI.0000018232.14085.75

Boschi, C., Früh-Green, G.L., Delacour, A., Karson, J.A., and Kelley, D.S., 2006. Mass transfer and fluid flow during detachment faulting and development of an oceanic core complex, Atlantis Massif (MAR $\left.30^{\circ} \mathrm{N}\right)$, Geochem. Geophys. Geosyst., 7:Q01004, doi:10.1029/2005GC001074.

Canales, J.P., Tucholke, B.E., and Collins, J.A., 2004. Seismic reflection imaging of an oceanic detachment fault: Atlantis megamullion (Mid-Atlantic Ridge, $30^{\circ} 10^{\prime} \mathrm{N}$ ). Earth Planet. Sci. Lett., 222:543-560; doi:10.1016/ j.eps1.2004.02.023.

Cann, J.R., Blackman, D.K., Smith, D.K., McAllister, E., Janssen, B., Mello, S., Avgerinos, E., Pascoe, A.R., and Escartin, J., 1997. Corrugated slip surfaces formed at ridge-transform intersections on the Mid-Atlantic Ridge. Nature, (London, U. K.), 385:329-332 ; doi:10.1038/ 385329a0.

Cannat, M., Karson, J.A., Miller, D.J., et al., 1995. Proc. ODP, Init. Repts., 153: College Station, TX (Ocean Drilling Program).

Cannat, M., Lagabrielle, Y., Bougault, H., Casey, J., de Coutures, N., Dmitriev, L., and Fouquet, Y., 1997. Ultramafic and gabbroic exposures at the Mid-Atlantic Ridge: geological mapping in the 15 degrees N region. Tectonophysics, 279:193-213; doi:10.1016/S0040-1951(97)00113-3.

Collins, J., Canales, J., and Tucholke, B., 2003. Seismic velocity structure of mid-Atlantic ridge core complexes: Geophysical Research Abstracts, Vol. 5, 10390.

Dick, H.J.B., Natland, J.H., Miller, D.J., et al., 1999. Proc. ODP, Init. Repts., 176. Available at http://www-odp.tamu.edu/ publications/176_IR/176TOC.HTM.

Dick, H.J.B., Natland, J.H., Alt, J.C., Bach, W., Bideau, D., Gee, J.S., Haggas, S., Hertogen, J.G.H., Hirth, G., Holm, P.M., Ildefonse, B., Iturrino, G.J., John, B.E., Kelley, D.S., Kikawa, E., Kingdon, A., LeRoux, P.J., Maeda, J., Meyer, P.S., Miller, D.J., Naslund, H.R., Niu, Y.-L., Robinson, P.T., Snow, J., Stephen, R.A., Trimby, P.W., Worm, H.-U., and Yoshinobu, A., 2000. A long in situ section of the lower ocean crust: results of ODP Leg 176 drilling at the Southwest Indian Ridge. Earth Planet. Sci. Lett., 179:31-51; doi:10.1016/S0012-821X(00)00102-3.

Escartin, J., Mével, C., MacLeod, C.J., and McCaig, A., 2003. Constraints on deformation conditions and the origin of oceanic detachments, the Mid-Atlantic Ridge core complex at $15^{\circ} 45^{\prime}$ N. Geochem. Geophys. Geosyst., 4(8):1067; doi:10.1029/2002GC000472.

Früh-Green, G.L., Kelley, D.S., Bernasconi, S.M., Karson, J.A., Ludwig, K.A., Butterfield, D.A., Boschi, C., and Proskurowksi, G., 2003. 30,000 years of hydrothermal activity at the Lost City vent field. Science, 301:495-498; doi:10.1126/science. 1085582 .

IODP Expeditions 304-305 Scientists, 2005. IODP Expeditions 304 and 305 : Oceanic Core Complex formation, Atlantis Massif. Scientific Drilling, 1:28-31.

Ildefonse, B., Blackman, D., John, B.E., Ohara, Y., Miller, D.J., MacLeod, C.J., and IODP Expeditions 304-305 Scientific Party, 2006. A revised model of oceanic core complex structure? Indications from IODP Expeditions 304-305, MidAtlantic Ridge, $30^{\circ} \mathrm{N}$, and previous ocean drilling results. 
Geophysical Research Abstracts, 8:05723; SRef-ID: 1607-7962/gra/EGU06-A-05723.

Johnson, K.T., Hellebrand, E., Abe, N., Andal, E., Brunelli, D., Charney, A., Christie, D., Hansen, H., Ishimaru, S., Maeda, J., Ohara, Y., Suhr, G., Tamura, A., Van der Handt, A., Yamasaki, T., and IODP Expedition 304-305 Scientific Party, 2005. Igneous petrology of Hole U1309D, IODP Expeditions $304 / 305$ at the Atlantis Massif, MAR $30^{\circ}$ N, Eos Trans. AGU, 86(52), Fall Meet. Suppl., Abstract T41D-1336.

Karson, J.A., Früh-Green, G.L., Kelley, D.S., Williams, E.A., Yoerger, D.R., and Jakuba, M., 2006. Detachment shear zone of the Atlantis Massif core complex, Mid-Atlantic Ridge, $30^{\circ} \mathrm{N}$, Geochem. Geophys. Geosyst., 7:Q06016; doi:10.1029/2005GC001109.

Kelemen, P.B., Kikawa, E., Miller, D.J., et al., 2004. Proc. ODP, Init. Repts., 209 Available at http://www-odp.tamu.edu/ publications/209_IR/209ir.htm.

Kelley, D.S., Karson, J.A., Früh-Green, G.L., Yoerger, D.R., Shank, T.M., Butterfield, D.A., Hayes, J.M., Schrenk, M.O., Olson, E.J., Proskurowski, G., Jakuba, M., Bradley, A., Larson, B., Ludwig, K., Glickson, D., Buckman, K., Bradley, A.S., Brazelton, W.J., Roe, K., Elend, M.J., Delacour, A., Bernasconi, S.M., Lilley, M.D., Baross, J.A., Summons, R. E., and Sylva, S.P., 2005. A serpentinite-hosted ecosystem: the Lost City hydrothermal field. Science, 307:1428-1434; doi:10.1126/science.1102556.

MacLeod, C.J., Escartin, J., Banerji, D., Banks, G.J., Gleeson, M., Irving, D.H.B., Lilly, R.M., McCaig, A.M., Niu, Y., Allerton, S., and Smith, D.K., 2002. Direct geological evidence for oceanic detachment faulting: the Mid-Atlantic Ridge, $15^{\circ} 45^{\prime} \mathrm{N}$. Geology, 30:10:879-882; doi:10.1130/00917613(2002)030<0879:DGEFOD > 2.0.CO;2.

Nooner, S.L., Sasagawa, G.S., Blackman, D.K., and Zumberge, M.A., 2003. Constraints on crustal structure at the Mid-Atlantic Ridge from seafloor gravity measurements made at the Atlantis Massif. Geophys. Res. Lett., 30:1446; doi:10.1029/2003GL017126.

Pettigrew, T.L., Casey, J.F., Miller, D.J., et al., 1999. Proc. ODP, Init. Repts., 179. Available from World Wide Web: http://wwwodp.tamu.edu/publications/179_IR/179TOC.HTM.

Robinson, P.T., Von Herzen, R.,,et al., 1989. Proc. ODP, Init. Repts., 118: College Station, TX (Ocean Drilling Program).

Schroeder, T., and John, B.E., 2004. Strain localization on an oceanic detachment fault system, Atlantis Massif, $30^{\circ} \mathrm{N}$, MidAtlantic Ridge. Geochem. Geophys. Geosyst., 5(11):Q11007 doi:10.1029/2004GC000728.

Singh, S.C., Collins, J.A., Canales, J.P., Tucholke, B.E., and Detrick, R.S., 2004. New insights into serpentinization at Atlantis Massif. Eos Trans. AGU 85(47), Fall Meet. Suppl. , Abstract V23B-0628.

Williams, E.A., Karson, J.A., Kelley, D.S., and Früh-Green, G.L., 2003. Cross-section of the Atlantis Massif - Geologic Framework for the Lost City Hydrothermal Vent Field. Eos Trans. AGU, 84(46), Fall Meet. Suppl., Abstract B12A-0774.

Wilson, D.S., Teagle, D.A.H., Alt, J.C., Banerjee, N.R., Umino, S., Miyashita, S., Acton, G.D., Anma, R., Barr, S.R., Belghoul, A., Carlut, J., Christie, D.M., Coggon, R.M., Cooper, K.M., Cordier, C., Crispini, L., Durand, S.R., Einaudi, F., Galli, L., Gao, Y.J., Geldmacher, J., Gilbert, L.A., Hayman, N.W.,
Herrero-Bervera, E., Hirano, N., Holter, S., Ingle, S., Jiang, S.J., Kalberkamp, U., Kerneklian, M., Koepke, J., Laverne, C., Vasquez, H.L.L., Maclennan, J., Morgan, S., Neo, N., Nichols, H.J., Park, S.H., Reichow, M.K., Sakuyama, T., Sano, T., Sandwell, R., Scheibner, B., Smith-Duque, C.E., Swift, S.A., Tartarotti, P., Tikku, A.A., Tominaga, M., Veloso, E.A., Yamasaki, T., Yamazaki, S., and Ziegler, C., 2006. Drilling to gabbro in intact ocean crust. Science, 312:1016-1020; doi:10.1126/science.1126090.

\section{Authors}

Benoit Ildefonse, CNRS, Laboratoire de Tectonophysique, Université Montpellier 2, 34095 Montpellier cedex 5, France, e-mail : benoit.ildefonse@univ-montp2.fr

Donna Blackman, Scripps Institution of Oceanography, University of California, San Diego, 9500 Gilman Drive, La Jolla, Calif. 92093-0225, U.S.A.

Barbara E. John, Department of Geology and Geophysics, University of Wyoming, 1000 East University Avenue, Department 3006, Laramie, Wyo. 82071, U.S.A.

Yasuhiko Ohara, Ocean Research Laboratory, Hydrographic and Oceanographic Department of Japan, 5-3-1 Tsukiji, Chuo-ku, Tokyo 104-0045, Japan

D. Jay Miller, Integrated Ocean Drilling Program, Texas A\&M University, 1000 Discovery Drive, College Station, Texas 77845-9547, U.S.A.

Christopher J. MacLeod, School of Earth, Ocean and Planetary Sciences, Cardiff University, Main Building, Park Place, Cardiff CF10 3YE, U.K.

and the IODP Expeditions 304-305 Scientists

\section{Related Web Links}

http://iodp.tamu.edu/scienceops/expeditions/exp304.html http://iodp.tamu.edu/scienceops/expeditions/exp305.html http://www-odp.tamu.edu/publications/176_IR/176TOC. HTM.

http://www-odp.tamu.edu/publications/209_IR/209ir.htm 